Org Lett. 2012 September 7; 14(17): 4442-4445. doi:10.1021/ol3019456.

\title{
Stereoselective Synthesis of Acortatarins A and B
}

\author{
Jacqueline M. Wurst ${ }^{\dagger}$, Alyssa L. Verano ${ }^{\ddagger}$, and Derek S. Tan ${ }^{\dagger, \ddagger, \S}$ \\ Derek S. Tan: tand@mskcc.org \\ †Tri-Institutional Training Program in Chemical Biology, Memorial Sloan-Kettering Cancer Center, \\ 1275 York Avenue, Box 422, New York, NY 10065 \\ ‡Pharmacology Program, Weill Cornell Graduate School of Medical Sciences, Memorial Sloan- \\ Kettering Cancer Center, 1275 York Avenue, Box 422, New York, NY 10065 \\ $\S$ Molecular Pharmacology \& Chemistry Program and Tri-Institutional Research Program, \\ Memorial Sloan-Kettering Cancer Center, 1275 York Avenue, Box 422, New York, NY 10065
}

\begin{abstract}

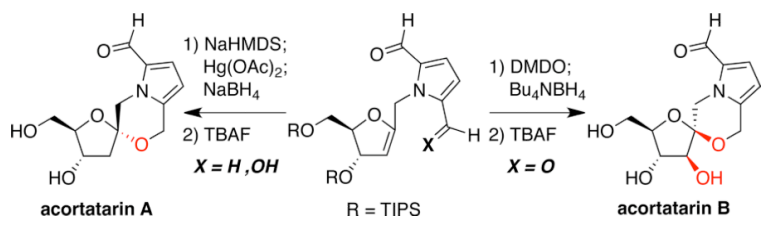

Acortatarins A and B have been synthesized via stereoselective spirocyclizations of glycals. Mercury-mediated spirocyclization of a pyrrole monoalcohol sidechain leads to acortatarin A. Glycal epoxidation and reductive spirocyclization of a pyrrole dialdehyde sidechain leads to acortatarin B. Acid equilibration and crystallographic analysis indicate that acortatarin B is a contrathermodynamic spiroketal with distinct ring conformations compared to acortatarin A.
\end{abstract}

Acortatarins A and B are novel spiroketal pyrrole alkaloids from the roots of Acorus tatarinowii (Figure 1). ${ }^{1}$ Structurally related pollenopyrrosides A and B were isolated contemporaneously from the pollen of Brassica campestris. ${ }^{2}$ Notably, acortatarins A and B exhibited significant antioxidant activity in a renal cell model for hyperglycemia-induced production of reactive oxygen species (ROS). ${ }^{1}$ Thus, these natural products are potential starting points for the development of new therapeutics to treat diabetic complications, cancer, and other conditions in which ROS are implicated. ${ }^{3}$ However, due to low isolation yields from the natural sources, ${ }^{4}$ efficient synthetic routes are needed to enable detailed biological evaluation. Herein, we report concise, modular syntheses of acortatarins A and B via stereoselective spirocyclizations of glycals. The thermodynamic preferences of both spiroketal natural products and the crystal structure of acortatarin B are also described.

In the original isolation paper, the relative configuration of acortatarin A was established by crystallography and an unnatural absolute $\mathrm{L}$-configuration was assigned based on Mosher analysis. ${ }^{1}$ An a-ribo relative configuration was assigned to acortatarin B based on ROESY analysis and the $\mathrm{L}_{\mathrm{-}}$-configuration assumed by analogy. Notably, pollenopyrroside B was separately assigned the enantiomeric ${ }_{\mathrm{D}}$-configuration of acortatarin $\mathrm{A}$ based on crystallographic analysis of its pyranose congener pollenopyrroside A (not shown). ${ }^{2}$

Correspondence to: Derek S. Tan, tandemskcc. org.

Supporting Information Available. Detailed experimental procedures and analytical data for all new compounds. This material is available free of charge via the Internet at http://pubs.acs.org. 
Subsequently, Sudhakar reported the first total syntheses of acortatarins A and B from 2deoxy-D-ribose and $\mathrm{D}$-arabinose, respectively, leading to structural revisions of both absolute configurations as well as the relative configuration of acortatarin B (Figure 1). ${ }^{5}$ Thus, acortatarin A and pollenopyrroside B are now recognized to be identical. A second synthesis of acortatarin A from D-mannitol was also reported recently by Brimble. ${ }^{6}$ These reports provide the first synthetic access to the acortatarins, but their practical utility is limited by low overall yields and reliance upon classical acid-catalyzed spiroketalization reactions that afford low or even undesired diastereoselectivity. ${ }^{7}$

Our laboratory has a long-standing interest in the stereocontrolled synthesis of spiroketals from glycals, , , 9, 10 and we envisioned that both acortatarins A and B could be synthesized by spirocyclizations of glycals 1 (Figure 2). Direct spirocyclization would provide acortatarin A while epoxidation-spirocyclization would lead to acortatarin B. In the latter case, we recognized that the oxidation state of the pyrrole substituents would be important for enabling chemoselective epoxidation of the glycal. These key intermediates 1 would originate from coupling of appropriate pyrroles 2 with ribal derivative 3 , accessed via nucleobase elimination of thymidine. ${ }^{11}$ At the outset of our studies, the revised structures of the acortatarins had not been reported but, recognizing that both enantiomers of thymidine are commercially available, initial work was carried out with the less expensive, natural D- $^{-}$ congener.

Thus, TIPS-protected ${ }^{12}$ ribal $6^{11}$ underwent $\mathrm{C} 1$-formylation ${ }^{13}$ and reduction to provide hydroxymethyl ribal 7 , which was then converted to iodide 8 (Figure 3). ${ }^{14}$ The pyrrole dicarboxaldehyde $9^{15,16}$ was then coupled under biphasic conditions ${ }^{17}$ to afford the key pyrrologlycal 10.

To access acortatarin A, we initially attempted reductive spirocyclization of dialdehyde $\mathbf{1 0}$ (TFA, $\mathrm{Et}_{3} \mathrm{SiH}$ ), envisioning cyclization of an aldehyde carbonyl followed by in situ reduction of the resulting spirocyclic oxocarbenium intermediate, but this led to a furan side product via Ferrier-type elimination (Figure S1). ${ }^{16}$ Similarly, stepwise reduction to monoalcohol 11 (Figure 4) followed by treatment with dichloroacetic acid led to a 1:1 mixture of a 2,3-dehydro-a-spiroketal (cf. 12) via Ferrier rearrangement and the undesired $\beta$-spiroketal 13. ${ }^{16}$

Thus, we next investigated oxidative spirocyclizations of pyrrole monoalcohol 11 that would yield spiroketals having a removable $\mathrm{C} 2$-substituent, and were delighted to find that treatment with $\mathrm{Hg}$ (II) salts afforded the desired 2-mercurial spiroketals, which were then reduced with $\mathrm{NaBH}^{4}$ to afford the diastereomeric spiroketals 12 and $13 .{ }^{9 \mathrm{~d}}$ Initial reactions with $\mathrm{Hg}(\mathrm{OAc})_{2}$ or $\mathrm{Hg}(\mathrm{TFA})_{2}$ led to modest stereoselectivity favoring the desired aspiroketal 12 (Table 1, entries 1-5). Notably, $\operatorname{Hg}(\mathrm{TFA})_{2}$ resulted in $30 \%$ formation of the same Ferrier rearrangement-derived 2,3-dehydro-a-spiroketal observed above (entry 2).

The $\mathrm{Hg}(\mathrm{OAc})_{2}$-derived 2-mercurial spiroketals exhibited a $7.8 \mathrm{~Hz} \mathrm{C} 2-\mathrm{H} / \mathrm{C} 3-\mathrm{H}$ coupling constant, consistent with a 2,3-trans relationship arising from $\beta$-mercuration (Figure S2). ${ }^{16}$

Since the expected anti-oxymercuration would then lead to the desired $\alpha$-spiroketal $12,{ }^{18}$ we postulate that the undesired $\beta$-spiroketal $\mathbf{1 3}$ arises from net syn-oxymercuration via an oxocarbenium intermediate. Thus, to accelerate anti-oxymercuration, pyrrole monoalcohol 11 was pretreated with NaHMDS to form a more reactive alkoxide nucleophile, resulting in increased stereoselectivity for the desired a-spiroketal 12 (entry 7). Surprisingly, however, longer reaction times prior to $\mathrm{NaBH}_{4}$ reduction led to further increased stereo-selectivity, indicative of an unanticipated equilibrium effect in this reaction (entries 6-10). Such equilibration was not observed without base, ${ }^{16}$ and other bases provided comparable or 
lower stereoselectivity. ${ }^{16}$ Desilylation of the mixture of $\mathbf{1 2}$ and $\mathbf{1 3}$ then provided the separable acortatarin A (14) and C1-epi-acortatarin A (15). ${ }^{16,19}$

Next, we pursued an epoxidation-spirocyclization approach to acortatarin B. ${ }^{91}$ In initial epoxidation studies, pyrrole monoalcohol $\mathbf{1 1}$ and its diol congener (not shown) were prone to pyrrole oxidation. In contrast, pyrrole dicarboxaldehyde $\mathbf{1 0}$ underwent chemoselective $\beta$ epoxidation of the glycal with DMDO to form the putative epoxide $\mathbf{1 6}$ (Figures 5 and S3). ${ }^{16}$ Addition of $\mathrm{NaBH}^{4}$ in $\mathrm{MeOH}$ afforded the a-spiroketal methanol adduct 22a (Table 2, entry 1). In contrast, $\mathrm{NaBH}_{4}$ in THF provided the desired $\beta$-spiroketal $\mathbf{1 7}$ as a single diastereomer, along with a tetracyclic side product 21 (entry 2). Attempted ionic reduction with $\mathrm{Et}_{3} \mathrm{SiH}$ resulted only in tetracycle $\mathbf{2 1}$ (entry 3 ). Conversely, reductive spirocyclization with acidic $\mathrm{NaBH}_{3} \mathrm{CN}$ yielded the epimeric a-spiroketal 18 and tetracycle 21 (entry 4). $\mathrm{NaBH}(\mathrm{OAc})_{3}$ led to a-spiroketal acetate adduct $\mathbf{2 2 b}$ (entry 5) while $\mathrm{LiEt}_{3} \mathrm{BH}$ and L-Selectride yielded complex mixtures (entries 6,7). Finally, $\mathrm{Bu}_{4} \mathrm{NBH}_{4}$, aided by its solubility in $\mathrm{CH}_{2} \mathrm{Cl}_{2}$, provided the desired $\beta$-spiroketal 17 in excellent yield and diastereoselectivity (entries 8,9 ). Spiroketals 17 and 18 were seperable and desilylation provided acortatarin B (19) and its C1-epimer (20). ${ }^{16,20}$

We next investigated acid-catalyzed equilibration of the natural products and their unnatural $\mathrm{C} 1$-anomers, as well as the TIPS-protected congeners $(\mathbf{1 2 - 1 5}, \mathbf{1 7 - 2 0}) .{ }^{21}$ In both series, the a-spiroketal was favored by a 65:35 ratio (Figures 4,5 ). ${ }^{16}$ Notably, this favors the unnatural anomer of acortatarin B. Accordingly, although it is commonly assumed that spiroketal biosynthesis is a spontaneous, thermodynamically-controlled process, acortatarin B is a contrathermodynamic spiroketal whose biosynthesis may be under enzymatic stereocontrol. ${ }^{22,23}$

Finally, we obtained a crystal structure of acortatarin B for comparison to the reported structure of acortatarin A (Figure 6). ${ }^{1}$ Interestingly, acortatarins A and B adopt distinct furanose envelope conformations ( $E_{1}$ vs. $E_{2}$ ) and morpholine half-chair conformations $\left({ }^{\mathrm{O}} H_{1}\right.$ vs. ${ }^{1} H_{\mathrm{O}}$ ) to allow double anomeric stabilization in both systems.

In conclusion, we have developed efficient, stereocontrolled syntheses of acortatarins A and B from a key pyrrologlycal 10. Acortatarin A was synthesized in 9 steps and 30\% overall yield from $\mathrm{D}$-thymidine, with 9:1 diastereoselectivity at the spiroketal-forming step and acortatarin B was accessed in 8 steps and $41 \%$ overall yield with complete diastereoselectivity. This compares favorably to previous syntheses ${ }^{7}$ and provides practical access to the natural products and a variety of analogues. Mechanistic analysis of the opposite stereoselectivities observed in these two spirocyclizations and biological studies are ongoing and will be reported in due course.

\section{Supplementary Material}

Refer to Web version on PubMed Central for supplementary material.

\section{Acknowledgments}

We thank Prof. Yong-Xian Cheng (Kunming Institute) for providing samples of the acortatarins, Dr. George Sukenick, Dr. Hui Liu, Hui Fang, and Dr. Sylvi Rusli (MSKCC) for expert NMR and mass spectral support, Dr. Kristen Kirschbaum (U. Toledo) for X-ray crystallographic analysis, and the NIH (P41 GM076267, T32 CA062948-Gudas) for financial support. 


\section{References}

1. Tong X-G, Zhou L-L, Wang Y-H, Xia C, Wang Y, Liang M, Hou F-F, Cheng Y-X. Org. Lett. 2010; 12:1844-1847. [PubMed: 20329735]

2. Guo J-L, Feng Z-M, Yang Y-J, Zhang Z-W, Zhang P-C. Chem. Pharm. Bull. 2010; 58:983-985. [PubMed: 20606352]

3. Valko M, Leibfritz D, Moncol J, Cronin MTD, Mazur M, Telser J. Int. J. Biochem. Cell Biol. 2007; 39:44-84. [PubMed: 16978905]

$4.50 \mathrm{~kg}$ A. tatarinowii root yielded $7.3 \mathrm{mg}$ acortatarin A and $3.4 \mathrm{mg}$ acortatarin B (ref 1); $15 \mathrm{~kg} \mathrm{~B}$. campestris pollen yielded $6 \mathrm{mg}$ pollenopyrroside A and $5 \mathrm{mg}$ pollenopyrroside B (ref 2).

5. Sudhakar G, Kadam VD, Bayya S, Pranitha G, Jagadeesh B. Org. Lett. 2011; 13:5452-5455. [PubMed: 21955040]

6. Geng HM, Chen JL-Y, Furkert DP, Jiang S, Brimble MA. Synlett. 2012; 23:855-858.

7. Ref 5 provides acortatarin A in $3.7 \%$ over 10 steps, with the key spirocyclization proceeding in 1.4:1 diastereoselectivity; accounting for epimerization of both anomers in a subsequent step to a 9:1 mixture favoring the desired diastereomer, the overall yield increases to $6.4 \%$. Acortatarin B is accessed in $0.9 \%$ yield over 10 steps, with the key spirocyclization proceeding in 1:4.6 unfavorable diastereoselectivity. Ref 6 provides acortatarin A in 1.7\% yield over 13 steps, with the key spirocyclization proceeding in 1.5:1 diastereoselectivity.

8. (a) Potuzak JS, Moilanen SB, Tan DS. J. Am. Chem. Soc. 2005; 127:13796-13797. [PubMed: 16201793] (b) Moilanen SB, Potuzak JS, Tan DS. J. Am. Chem. Soc. 2006; 128:1792-1793. [PubMed: 16464069] (c) Liu G, Wurst JM, Tan DS. Org. Lett. 2009; 11:3670-3673. [PubMed: 19634891] (d) Wurst JM, Liu G, Tan DS. J. Am. Chem. Soc. 2011; 133:7916-7925. [PubMed: 21539313]

9. For selected early studies on the synthesis of spiroketals from cyclic enol ethers, see: Knabe J, Schaller K. Arch. Pharm. 1968; 301:457-464. Clark-Lewis JW, McGarry EJ. Aust. J. Chem. 1975; 28:1145-1147. Boeckman RK Jr, Bruza KJ, Heinrich GR. J. Am. Chem. Soc. 1978; 100:71017103. Danishefsky SJ, Pearson WH. J. Org. Chem. 1983; 48:3865-3866. Amouroux R. Heterocycles. 1984; 22:1489-1492. Iwata C, Hattori K, Uchida S, Imanishi T. Tetrahedron Lett. 1984; 25:2995-2998. Cremins PJ, Wallace TW. J. Chem. Soc. Chem. Commun. 1986:1602-1603. Bernet B, Bishop PM, Caron M, Kawamata T, Roy BL, Ruest L, Soucy P, Deslongchamps P. Can. J. Chem. 1985; 63:2814-2818. Yeates C, Street SDA, Kocienski P, Campbell SF. J. Chem. Soc. Chem. Commun. 1985:1388-1389. Diez-Martin D, Grice P, Kolb HC, Ley SV, Madin A. Tetrahedron Lett. 1990; 31:3445-3448. Kurth MJ, Olmstead MM, Rodriguez MJ. J. Org. Chem. 1990; 55:283-288. Friesen RW, Sturino CF. J. Org. Chem. 1990; 55:5808-5810. Dubois E, Beau JM. Tetrahedron Lett. 1990; 31:5165-5168. Jeong JU, Fuchs PL. J. Am. Chem. Soc. 1994; 116:773-774. Boyce RS, Kennedy RM. Tetrahedron Lett. 1994; 35:5133-5136. Holson EB, Roush WR. Org. Lett. 2002; 4:3719-3722. [PubMed: 12375927]

10. For asymmetric variants, see: Uchiyama M, Oka M, Harai S, Ohta A. Tetrahedron Lett. 2001; 42:1931-1934. Coric I, List B. Nature. 2012; 483:315-319. [PubMed: 22422266] Sun Z, Winschel GA, Borovika A, Nagorny P. J. Am. Chem. Soc. 2012; 134:8074-8077. [PubMed: 22545651]

11. Cameron MA, Cush SB, Hammer RP. J. Org. Chem. 1997; 62:9065-9069.

12. Friesen RW, Sturino CF, Daljeet AK, Kolaczewska A. J. Org. Chem. 1991; 56:1944-1947.

13. Paquette LA, Schulze MM, Bolin DG. J. Org. Chem. 1994; 59:2043-2051.

14. Gallier F, Hussain H, Martel A, Kirschning A, Dujardin G. Org. Lett. 2009; 11:3060-3063. [PubMed: 19537770]

15. Muchowski JM, Hess P. Tetrahedron Lett. 1988; 29:777-780.

16. See Supporting Information for full details.

17. Lopez-Perez A, Robles-Machin R, Adrio J, Carretero JC. Angew. Chem. Int. Ed. 2007; 46:92619264.

18. Inglis GR, Schwarz JCP, McLaren L. J. Chem. Soc. 1962:1014-1019. Takiura K, Honda S. Carbohydr. Res. 1972; 21:379-391. (c) General review: Chatt J. Chem. Rev. 1951; 48:7-43. 
19. The optical rotation of synthetic $\mathrm{D}$-acortatarin $\mathrm{A}(\mathbf{1 4}),[\mathrm{a}]_{\mathrm{D}}^{19}:+200(c 0.4, \mathrm{MeOH})$, matched that of an authentic sample, $[\mathrm{a}]_{\mathrm{D}}^{19}:+199(c 0.4, \mathrm{MeOH})$, confirming the revised absolute stereochemical assignment as 2-deoxy-D-ribo (refs. 5, 6).

20. The optical rotation of synthetic acortatarin B (19), $[\mathrm{a}]_{\mathrm{D}}^{27}:-92.7(c 0.1, \mathrm{MeOH})$, matched that of an authentic sample, $[\mathrm{a}]_{\mathrm{D}}^{27}:-92.9(c 0.1, \mathrm{MeOH})$. Examination of the NOESY spectrum of acortatarin $\mathrm{B}$, in comparison to the original ROESY spectrum (ref 1) suggests that mis-assignment of the relative C2-C3 stereochemistry was due to assignment of ambiguous C2-H/C5- $\mathrm{H}_{2}$ crosspeaks, and to non-assignment of an ambiguous C8-H/C5-H crosspeak (Figure S4). Notably, in the structural revision paper (ref 5), $\mathrm{C} 2-\mathrm{H} / \mathrm{C} 5-\mathrm{H}_{2}$ ROESY crosspeaks also appear but were apparently discounted in favor of clear $\mathrm{C} 5-\mathrm{H} / \mathrm{C} 8-\mathrm{H}_{2}$ crosspeaks. The reported $7.7 \mathrm{~Hz} \mathrm{C} 2-\mathrm{H} / \mathrm{C} 3-\mathrm{H}$ coupling constant is also more consistent with a 2,3-trans relationship: Lemieux RU, Stevens JD. Can. J. Chem. 1966; 44:249-262.

21. In contrast to 6-membered ring spiroketals, the conformational flexibility of 5-membered rings makes such thermodynamic preferences difficult to predict a priori based on anomeric stabilization: Deslongchamps P, Rowan DD, Pothier N, Sauve T, Saunders JK. Can. J. Chem. 1981; 59:1105-1121. Tlais SF, Dudley GB. Org. Lett. 2010; 12:4698-4701. [PubMed: 20860404]

22. (a) Gallimore AR, Stark CBW, Bhatt A, Harvey BM, Demydchuk Y, Bolanos-Garcia V, Fowler DJ, Staunton J, Leadlay PF, Spencer JB. Chem. Biol. 2006; 13:453-460. [PubMed: 16632258] (b) Takahashi S, Toyoda A, Sekiyama Y, Takagi H, Nogawa T, Uramoto M, Suzuki R, Koshino H, Kumano T, Panthee S, Dairi T, Ishikawa J, Ikeda H, Sakaki Y, Osada H. Nat. Chem. Biol. 2011; 7:461-468. [PubMed: 21642985]

23. For a review on nonanomeric spiroketals, many of which are contrathermodynamic, see: Aho JE, Pihko PM, Rissa TK. Chem. Rev. 2005; 105:4406-4440. [PubMed: 16351049] 


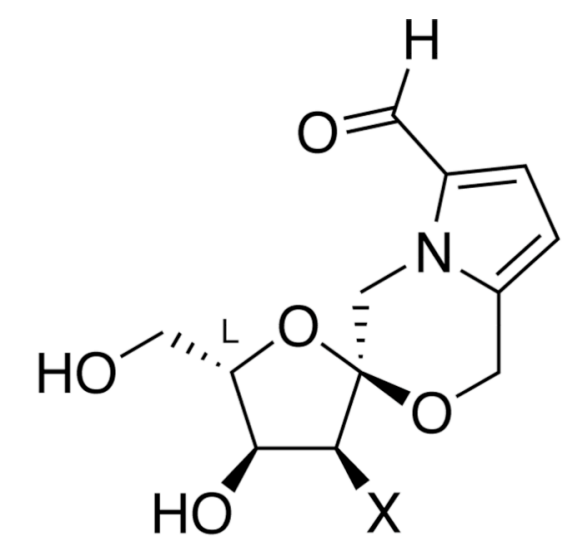

original structures acortatarin $A(X=H)$ acortatarin $\mathbf{B}(\mathrm{X}=\mathrm{OH})$

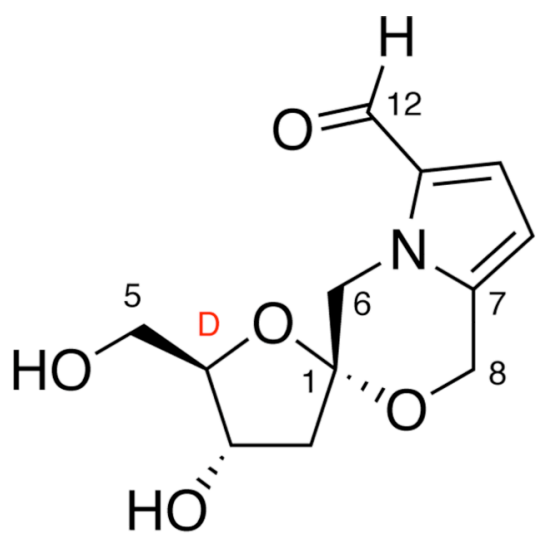

revised structure acortatarin $\mathrm{A}$ (pollenopyrroside B)

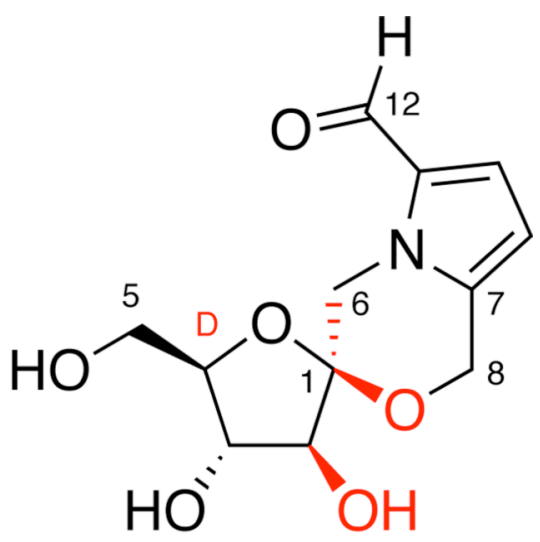

revised structure acortatarin B

Figure 1.

Original $^{1}$ and revised ${ }^{5}$ structures of the acortatarins. 
<smiles>[R][C@@H]1[C@@H](O)[C@@H](CO)O[C@]12Cn1c(C=O)ccc1CO2</smiles>

original structures acortatarin $A(R=H)$ acortatarin $\mathbf{B}(\mathrm{R}=\mathrm{OH})$

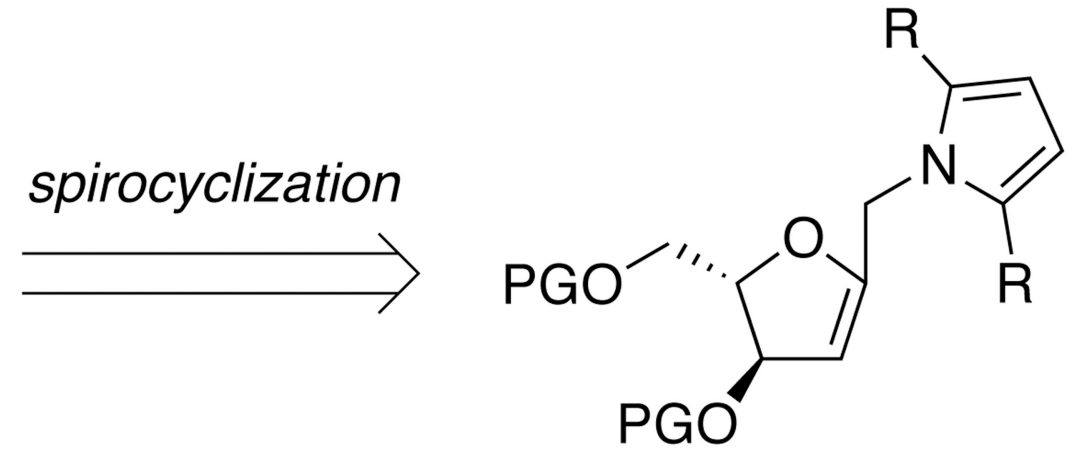

$1\left(\mathrm{R}=\mathrm{CHO}\right.$ or $\left.\mathrm{CH}_{2} \mathrm{OH}\right)$<smiles>[R]c1ccc([R])[nH]1</smiles>

alkylation
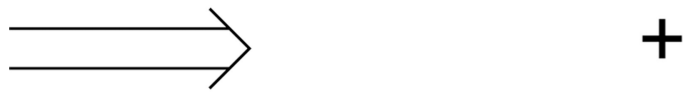

$2\left(\mathrm{R}=\mathrm{CHO}\right.$ or $\left.\mathrm{CH}_{2} \mathrm{OPG}\right)$

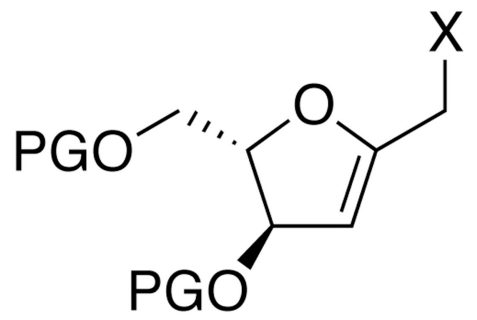

3
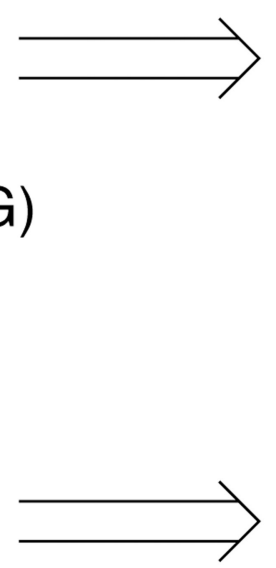

Figure 2.

Retrosynthetic analysis of acortatarins A and B (original structures) via key pyrrologlycal intermediates 1 .<smiles>O=Cc1ccc[nH]1</smiles><smiles>Cc1cn(C2C[C@@H](O)[C@@H](CO)O2)c(=O)[nH]c1=O</smiles>

L-thymidine 


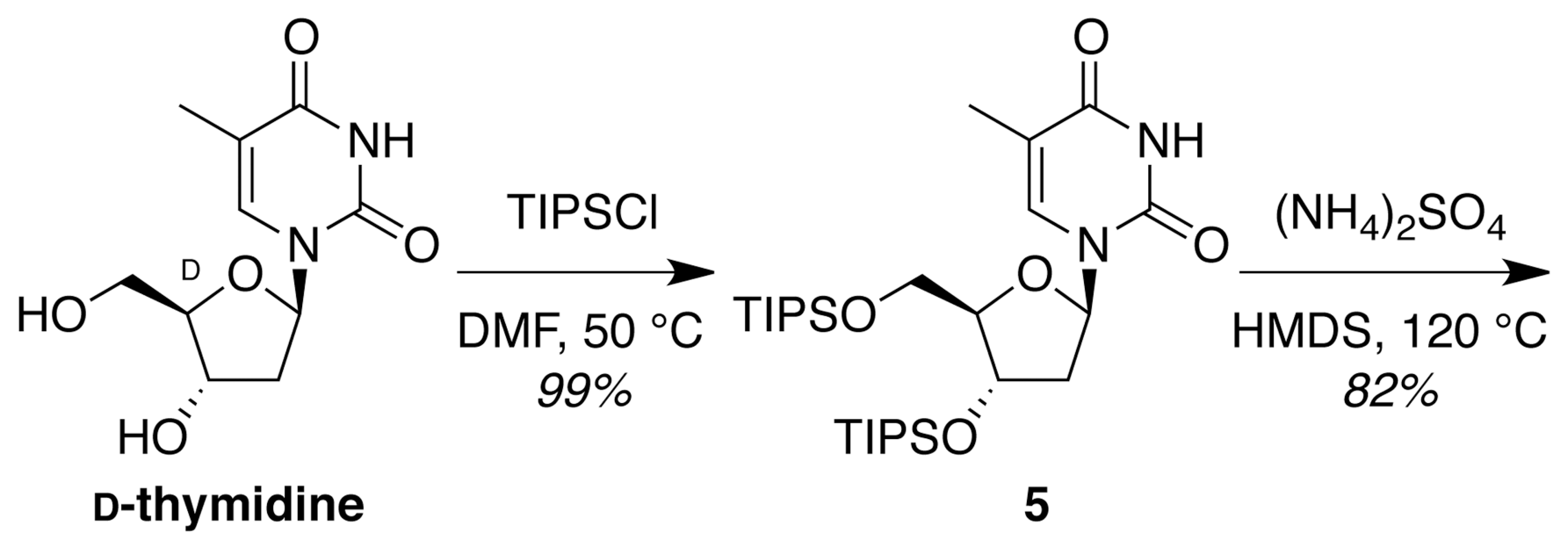

1) $t$-BuLi; DMF

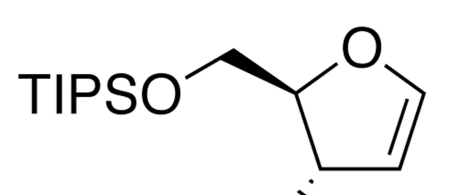

TIPSO"

6
$\mathrm{THF},-78^{\circ} \mathrm{C} \rightarrow \mathrm{rt}$

2) $\mathrm{NaBH}_{4}$ $\mathrm{MeOH},-78^{\circ} \mathrm{C}$ $78 \%$ over 2 steps<smiles>O=Cc1ccc(C=O)[nH]1</smiles><smiles>FS(F)(F)OC[C@@H]1CC=C(CI)O1</smiles>
TIPSO"

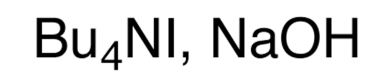

toluene, $\mathrm{H}_{2} \mathrm{O}$ $0^{\circ} \mathrm{C} \rightarrow 50{ }^{\circ} \mathrm{C}$ $93 \%$
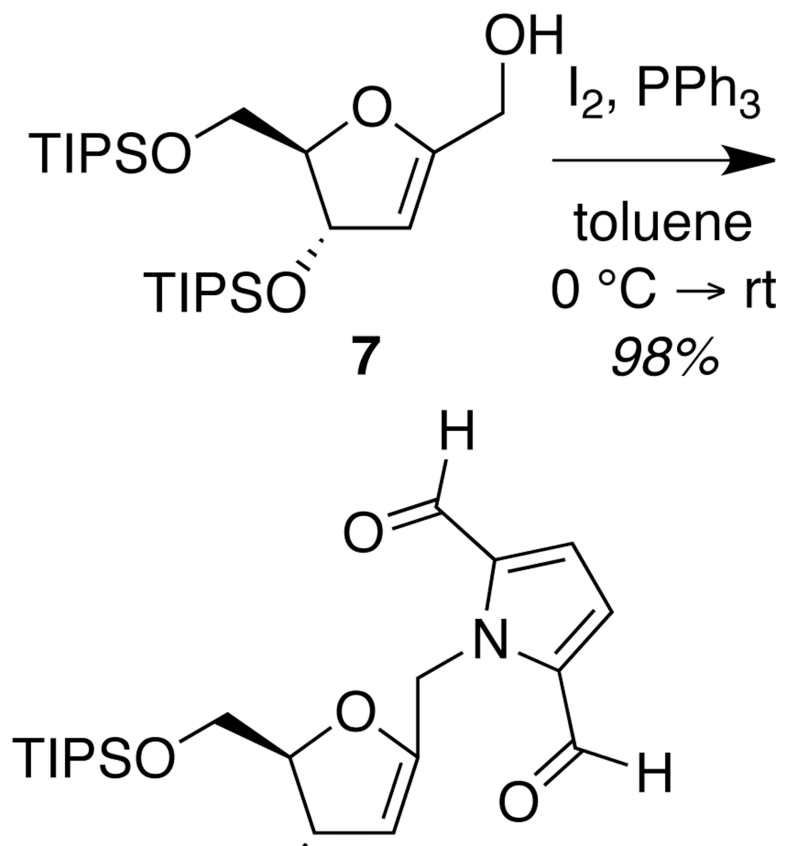

TIPSO"

10

Figure 3.

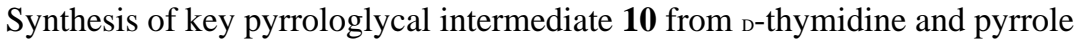
dicarboxaldehyde $\mathbf{9}$. 
<smiles>O=Cc1ccc(C=O)n1CC1=CC[C@@H](COS(F)(F)F)O1</smiles>

TIPSO

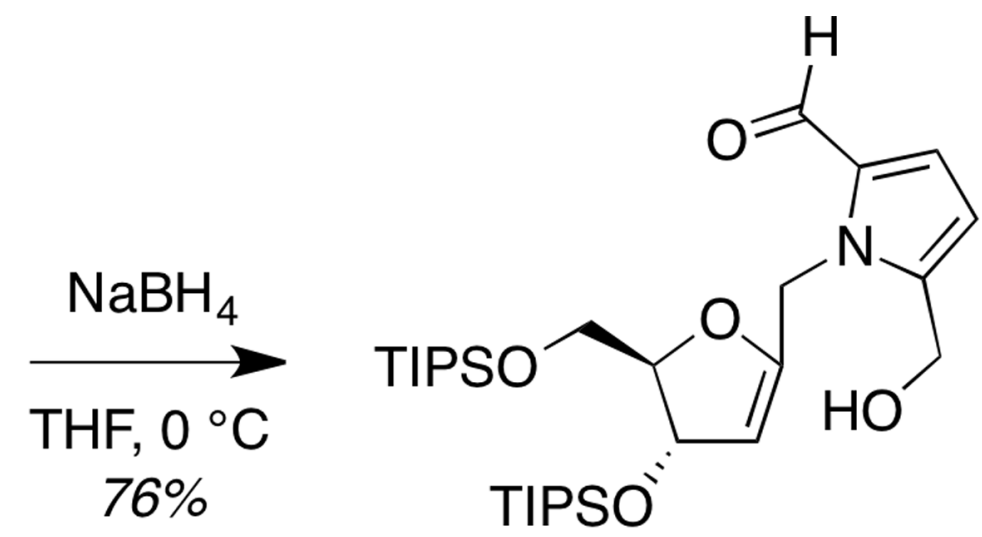

11

\section{0}

1) NaHMDS

Figure 4.
$\mathrm{THF},-78^{\circ} \mathrm{C}$; $\mathrm{Hg}(\mathrm{OAc})_{2}$

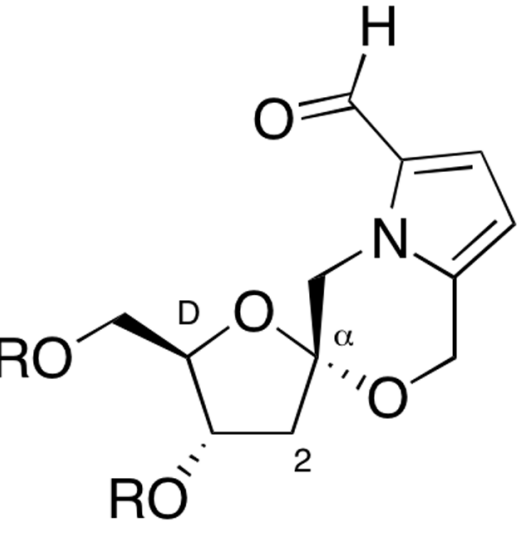

TBAF, THF $0{ }^{\circ} \mathrm{C}, 69 \%$ (12 ( $\left.\mathrm{R}=\mathrm{TIPS}\right)$ over 2 steps $14(\mathrm{R}=\mathrm{H}$, acortatarin $\mathrm{A})$

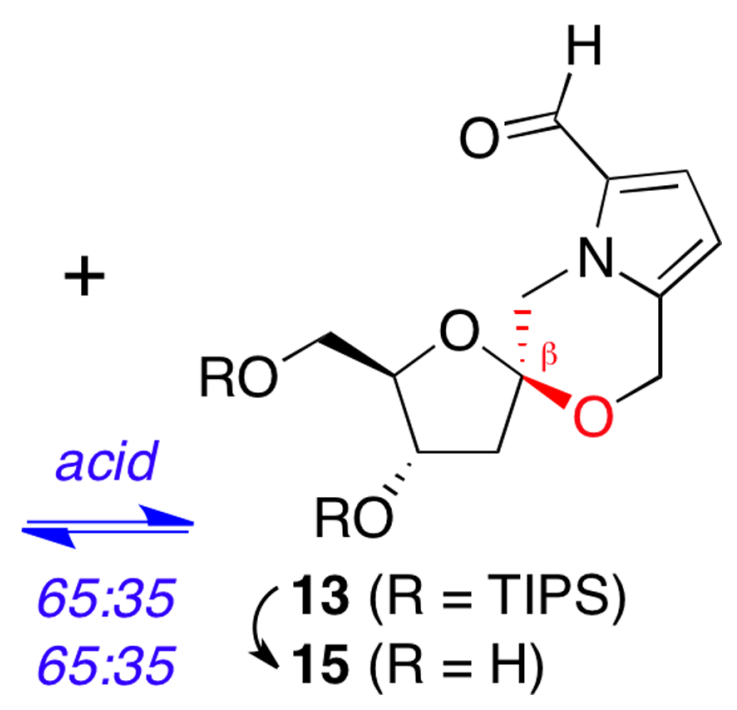

Synthesis of acortatarin A (14) via mercury-mediated spirocyclization of pyrrole monoalcohol 11. Acid equilibration of spiroketals 12-15 favors the a-spiroketals. 
<smiles>O=Cc1ccc(C=O)n1CC1=C[C@@H](O[AsH3])[C@@H](COS(F)(F)F)O1</smiles>

10
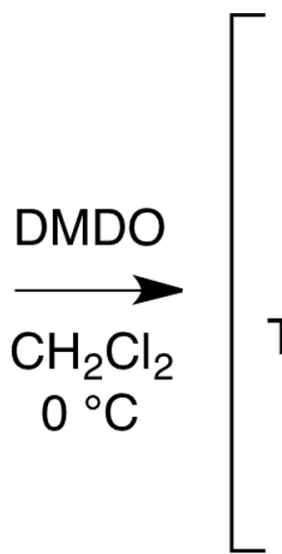
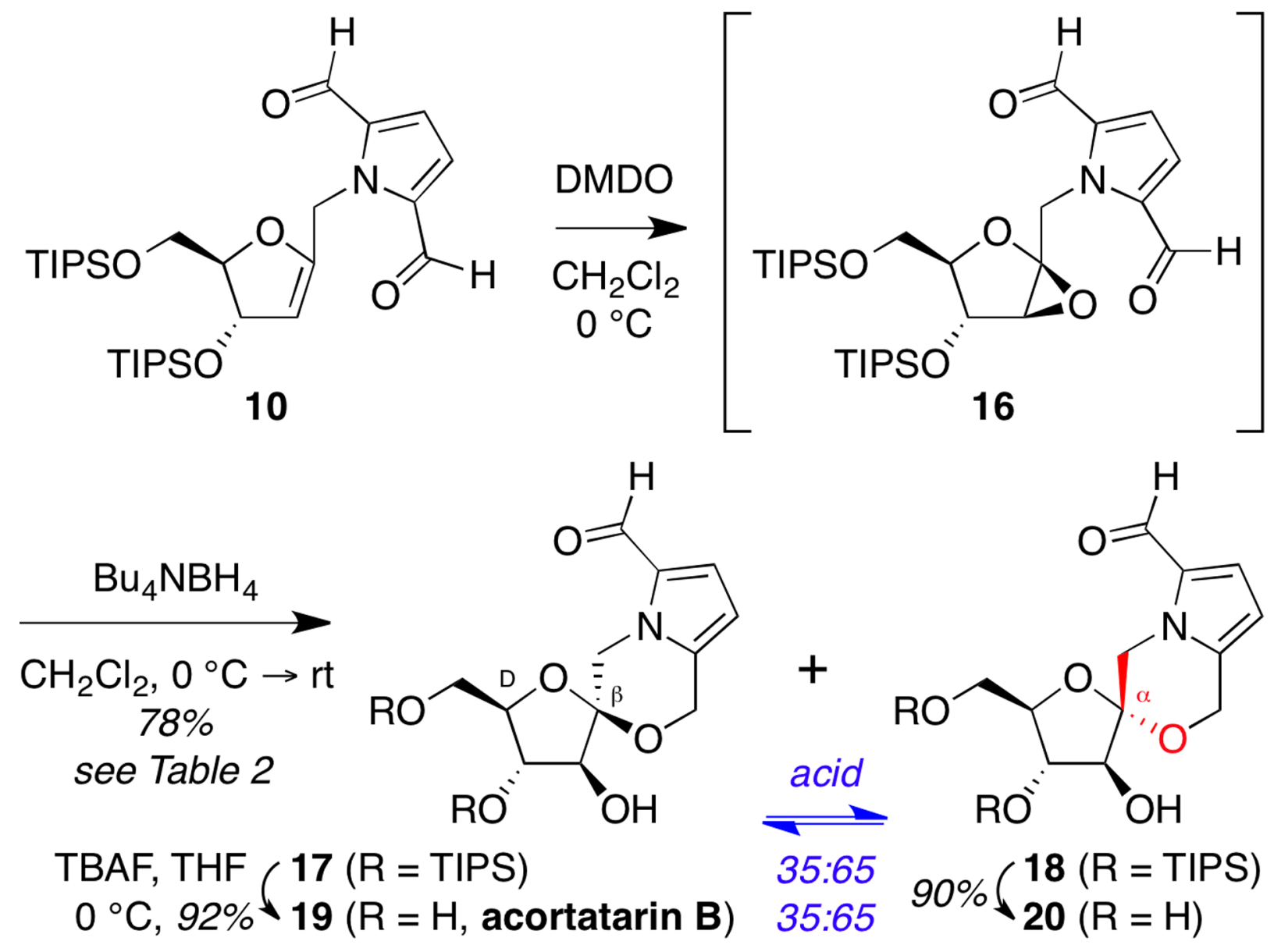

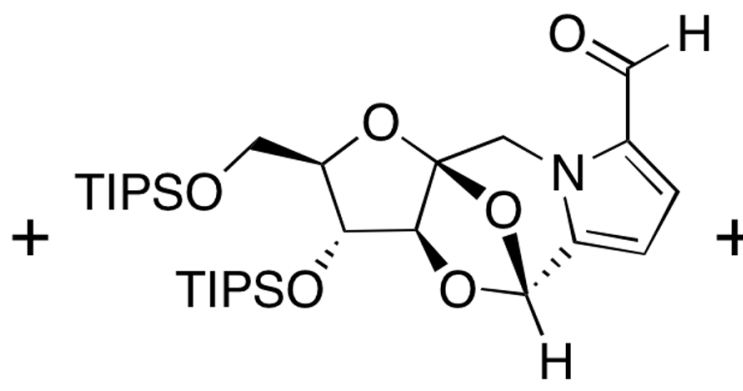

21

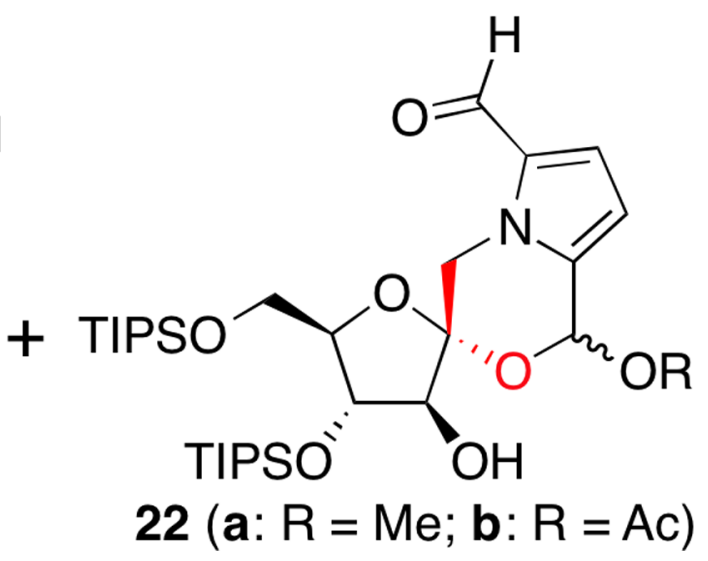

Figure 5.

Synthesis of acortatarin B (19) via epoxidation and reductive spirocyclization of pyrrole dicarboxaldehyde 10. Acid equilibration of spiroketals 17-20 favors the a-spiroketals. 


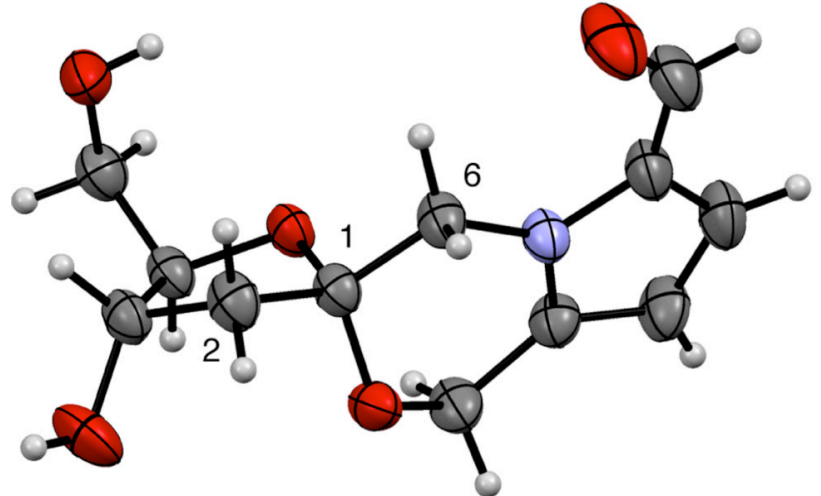

acortatarin A (14)

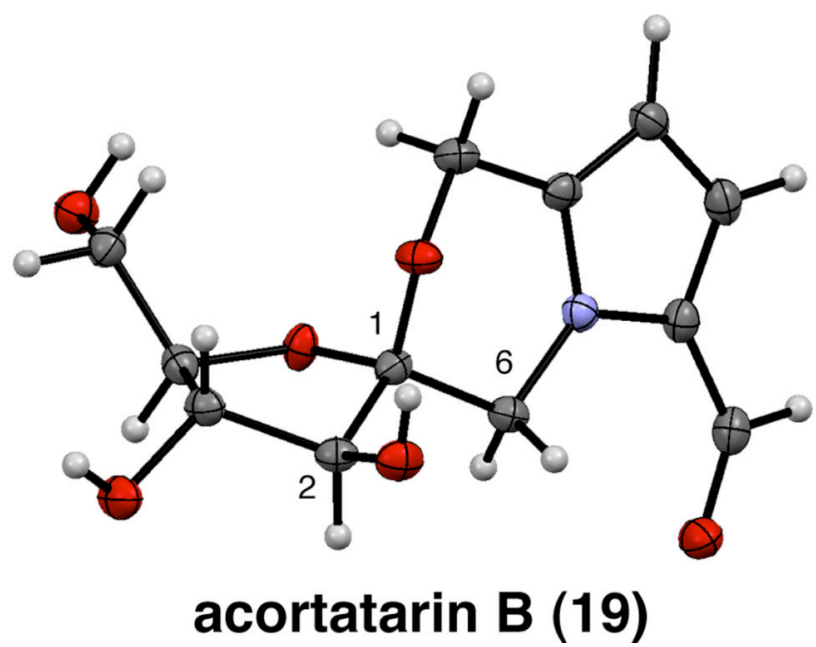

Figure 6.

Crystal structures of acortatarin $\mathrm{A}^{1}$ and acortatarin $\mathrm{B}$ reveal distinct ring conformations and double anomeric stabilization. $50 \%$ probability ellipsoids shown for heavy atoms. 


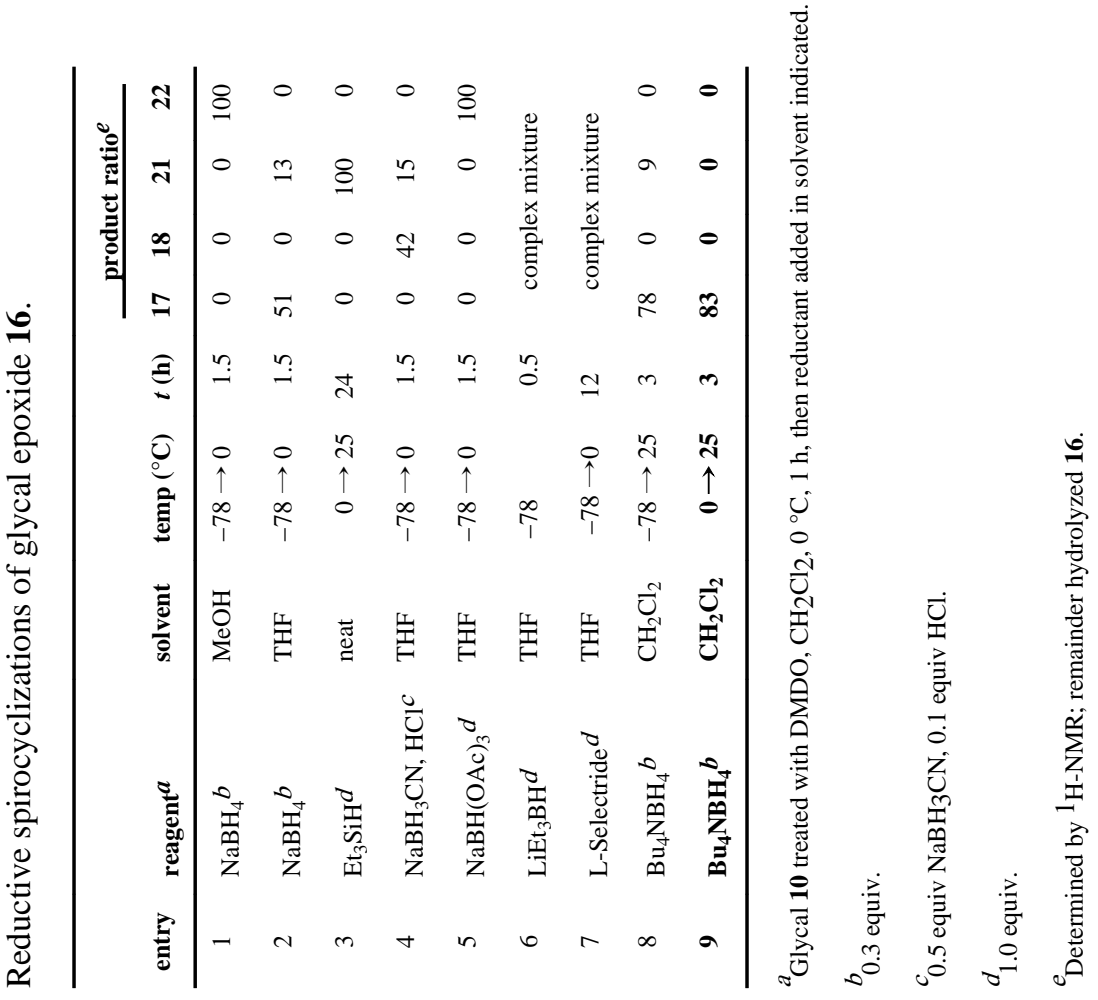

